\title{
Analysis of retinol, $\beta$-carotene, vitamin E, and cholesterol contents in steamed and braised dishes of the Korean diet
}

\author{
Hyun-Gyu Moon, Md. Atiqual Islam, Jiyeon Chun* \\ Department of Food Science and Technology, Sunchon National University, Suncheon 57922, Korea
}

\section{한국 식단의 찜류 및 조림류의 지용성 비타민 및 콜레스테롤 함량 분석 및 검증}

\author{
문현규·무하마드 아티큐얼 이슬람·천지연* \\ 순천대학교 식품과학부 식품공학전공
}

\begin{abstract}
Steamed and braised dishes (SBDs) are staples of the Korean diet; therefore, knowledge of their nutritional contents is important for public health. To investigate the nutritional value of these foods, 25 different SBDs prepared following standard recipes were analyzed for retinol, $\beta$-carotene, vitamin $\mathbf{E}$, and cholesterol contents using saponification coupled with GC and HPLC. To ensure the reliability of the data, the analytical methods were validated. The method showed acceptable precision (repeatability 0.9-1.3\% RSD and reproducibility 1.1-5.9\% RSD) and accuracy (95.6-101.1\% recovery). The concentrations of the fat-soluble components in the SBDs varied widely depending on the constituent ingredients; cholesterol, retinol, $\beta$-carotene, and vitamin $E$ concentrations were 0.0-246.7 mg/100 $\mathrm{g}$, 0-155.1 $\mu \mathrm{g} / 100 \mathrm{~g}$, 0-1203.2 $\mu \mathrm{g} / 100 \mathrm{~g}$, and 0.09-1.85 mg a-tocopherol (T) equivalent/100 g, respectively. The highest retinol and $\beta$-carotene concentrations were observed in steamed egg with milk and braised egg, respectively, while neither was detected in braised mushroom or lotus root. SBDs prepared with egg showed the highest contents of cholesterol, vitamin $A$ and $E$. The a-T form of vitamin $E$ was detected in all SBDs and was predominant in most dishes, followed by $\gamma$-T. $\gamma$-Tocotrienol was a lesser ubiquitous form of vitamin $E$ and detected only in Kkwarigochu-jjim and Eomuk-jorim. This work can help to provide nutritional guidance regarding the typical diet of the Korean population.
\end{abstract}

Key words : retinol, $\beta$-carotene, vitamin $\mathrm{E}$, cholesterol, Korean diet

\section{서 론}

만성 질환의 발병이 생활습관 및 식습관과의 관련성이 높다고 밝혀지면서 질병 예방 및 건강관리를 위한 올바른 식단 관리에 대한 관심이 높아지고 있다(1,2). 영양소 섭취 수준의 평가를 통한 건강한 식습관 관리는 국민건강보건정 책의 기본선행 요건으로 국외 선진 국가에서는 일찍부터 국민들의 다소비 식품군들에 대한 영양성분 데이터베이스

*Corresponding author. E-mail : cjyfall@gmail.com

Phone : 82-61-750-3258, Fax : 82-61-750-3250

Received 10 October 2019; Revised 16 October 2019; Accepted 17 October 2019.

Copyright (c) The Korean Society of Food Preservation. All rights reserved. (database, DB)를 구축하여 국민들에게 제공할 뿐 아니라 이를 기본으로 하는 국민보건정책 및 질병관리를 위한 기초 자료로 활용하고 있다. 미국 농무성(United States Department of Agriculture, USDA)은 1997년 이래 지속적으 로 식품에 대한 영양소 정보를 구축하고 이를 국민건강영양 조사에 활용하고 있으며(3), 일본 문부과학성에서도 일본 식품표준성분표를 지속적으로 개정 발행하고 있다(4). 국 내에서는 농촌진흥청에서 국가식품성분표를 지속적으로 발간하고 있고, 식품의약품안전처에서는 외식 및 가공식품 등 음식의 영양성분에 대한 분석 데이터베이스를 구축하고 있으며, 이러한 자료들은 식품안전정보포털 식품안전나라 를 통해 국가식품영양성분 $\mathrm{DB}$ 로 제공되고 있다(5).

최근 이러한 국민 다소비 식품에 대한 영양성분 $\mathrm{DB}$ 구축 의 필요성은 탄수화물, 지방, 단백질 등과 같은 다량 영양소 
이외에 비타민과 같은 필수 미량영양성분으로 확산되고 있다. 이는 비타민은 인체 내에서 에너지 생성이나 신체 구성에는 관여하지 않으나 물질 대사와 생리작용을 조절하 기 위한 필수 주요 성분으로, 동물 체내에서는 합성이 되지 않거나 극히 소량이 합성되기 때문에 반드시 식품이나 보조 제를 통해 섭취해야만 관련 결핍 증상을 예방할 수 있기 때문이다(6). Kim 등(7)의 연구에 따르면 식품군에 따른 비타민 A 섭취 기여정도는 채소류가 가장 높았고 조미료, 해조류, 과일류의 순으로 기여하고 있으며 우리나라 성인 비타민 $\mathrm{A}$ 섭취량을 평가한 결과, 영양섭취 권장기준에 비하 여 매우 부족한 수준인 것으로 나타났다. 또한, Ahn 등(8)은 식이를 통한 비타민 $\mathrm{E}$ 섭취 기여정도는 채소류가 가장 높았 으며, 기여 식품군으로는 곡류, 난류 순이었으며, 식이를 통한 비타민 $\mathrm{E}$ 섭취량은 꾸준히 증가하고 있으나 한국인 영양소 충분섭취량 기준에는 미치지 못하고 있다고 보고하 였다. 식이로부터 충분한 수준의 지용성 비타민 섭취를 위 해서는 지방 함량이 높은 식품의 섭취가 효과적이나 지방함 량이 높은 동물성 식품의 경우 지용성 비타민 외에 콜레스 테롤을 동반 섭취할 수 있으므로 동물성 재료를 포함하는 식이의 경우 지용성 비타민에 관한 $\mathrm{DB}$ 와 함께 콜레스테롤 과 같은 관리가 필요한 성분에 대한 정보 제공이 필요하다. Park 등(9)은 한국인 식단으로부터의 콜레스테롤 평균 섭취 량은 콜레스테롤 목표섭취량 이하이나 최근 젊은 연령층의 콜레스테롤 평균 섭취량은 목표섭취량을 초과하는 수준이 라고 보고하여 건강한 식생활을 위해서는 지용성 비타민 섭취 수준과 함께 콜레스테롤 섭취 수준도 함께 고려하는 것이 필요하다.

지금까지 국내에서는 농진청, 식약처, 국립수산과학원, 한국영양학회 등 다양한 기관에서 한국 식품영양성분에 $\mathrm{DB}$ 구축을 위한 분석법 검증 및 영양성분 분석 연구들이 수행되어왔다. 이러한 연구의 일환으로 Park 등(10)은 한국 의 지역별 특화 음식에 함유된 비타민 $\mathrm{A}, \mathrm{E}$ 및 콜레스테롤 함량 분석 연구, $\operatorname{Kim}$ 등(11)은 한국 외식식품 중 밥류, 국 (탕) 및 찌개류에 함유된 베타카로틴과 레티놀 함량 분석 연구, Park 등(12)은 한국 농산가공 식품에 함유된 비타민 $\mathrm{E}$ 함량 분석 연구 등이 수행되어 국내 다소비 주요 식품들의 지용성 성분에 관한 정보를 제공하였다. 지금까지 국내 식 품영양성분 $\mathrm{DB}$ 구축은 주로 지역 특화식품, 전국 음식점에 서 수거된 외식 식품, 가공식품들이 대부분이었으며 외식 식품의 경우 지역별 조리법 및 재료의 다양성으로 인하여 성분함량의 범위가 비교적 넓어 한국 식단의 영양성분 대푯 값 산출을 위해서는 국내 식품을 표준화하여 영양성분 DB 를 구축에 대한 필요성이 대두되고 있다(10). 국내 외식 또는 가정식 식단에서 찜류 및 조림류는 육류, 어류 및 채소 류 등의 다양한 재료를 사용하여 주로 장시간 가열을 통해 조리되는 식품으로 지용성 성분들이 풍부한 식품들이다 (13). 이러한 재료들은 한국인 영양성분 섭취빈도 중 비타민
$\mathrm{A}, \mathrm{E}$ 및 콜레스테롤의 섭취가 높은 재료들로 이루어져 있으 나 이들 성분에 관한 데이터는 미비한 실정이다.

따라서, 본 연구에서는 한국인의 영양소별 누적섭취 기 여도를 고려한 key food 식품 중 외식 및 가정식 찜류 및 조림류 25종을 선정하고 이를 표준 조리법으로 조리한 후 이들에 대한 비타민 $\mathrm{A}, \mathrm{E}$ 및 콜레스테롤 함량을 분석하여 $\mathrm{DB}$ 구축 자료로 제공하고자 하였다. 또한, 국가식품영양성 분 $\mathrm{DB}$ 구축을 위한 분석품질 향상 및 분석 신뢰도 확보를 위해 비타민 $\mathrm{A}, \mathrm{E}$ 및 콜레스테롤 분석에 대한 검증 및 분석 품질관리를 수행하였다.

\section{재료 및 방법}

\section{시약 및 재료}

콜레스테롤 분석을 위해 외부표준품(external standard)으 로 cholesterol(Tokyo Chemical Industry, Tokyo, Japan)과 내 부표준품(internal standard, IS)으로 5a-cholestane(SigmaAldrich Co., St. Louis, MO, USA)을 사용하였으며, 비타민 $\mathrm{A}$ 분석을 위한 retinol과 $\beta$-carotene, 비타민 $\mathrm{E}$ 분석을 위한 tocopherol과 tocotrienol 표준품은 Sigma-Aldrich Co.에서 구입하여 사용하였다. 기타 사용된 시약 및 용매는 특급 및 $\mathrm{HPLC}$ 등급을 사용하였다. 분석법의 정확성 검증을 위해 사용한 표준참고물질(standard reference material, SRM)은 SRM 1849a(infant/adult nutritional formula)와 SRM 3251(saw palmetto)이었으며 National Institute of Standards and Technology(NIST, Gaithersburg, MD, USA)에서 구입하 여 사용하였다.

\section{시료 제조 및 전처리}

본 실험에서 분석한 찜류 및 조림류 메뉴 25 종은 한국인 의 식습관과 섭취량을 고려하여 주요 식품(key food) 선정 프로그램을 활용하여 선정하였다. 선정된 식품은 농촌진흥 청, 식품의약품안전처, 대한영양사협회, 검색 등 표준화된 레시피를 대상으로 식품의약품안전처 선정에 따라 조리되 었다. 조리된 식품은 균질화 과정을 거친 후 National Laboratory System(NLS) 센터(Sookmyung Women's University, Seoul, Korea)에서 드라이아이스와 아이스팩으 로 포장한 후 분석기관으로 배송되었다. 배송된 시료는 $70^{\circ} \mathrm{C}$ 에서 보관하며 분석에 사용하였다.

\section{지용성 성분 추출(saponification)}

추출관에 $5 \mathrm{~g}$ 의 시료를 취하고 $6 \%$ pyrogallol ethanol 용액 을 $10 \mathrm{~mL}$ 첨가한 후 10 분간 초음파처리(sonicator, Cole-Parmer 8893, Chicago, IL, USA) 하여 시료와 균질하게 섞이도록 하였다. 다음으로 추출관에 $60 \% \mathrm{KOH}$ 용액을 $8 \mathrm{~mL}$ 를 가하여 혼합하고 추출관의 상부에 질소를 주입하여 
공기를 치환시켰다. 치환 후 추출관에 air condenser를 부착 하여 shaking water bath(HB-205SW, Hanbaek Scientific Co., Bucheon, Korea)에서 1 시간 동안 $75^{\circ} \mathrm{C}, 100 \mathrm{rpm}$ 으로 검화 (saponification)하였다. 검화가 끝난 후 충분히 냉각한 검화 액에 $2 \% \mathrm{NaCl}$ 용액을 $20 \mathrm{~mL}$ 가하여 반응을 종결시켰다. 검화액에 추출용매(hexane:ethyl acetate $=85: 15, \mathrm{v} / \mathrm{v}, 0.01 \%$ 2,6-di-tert-butyl-4-methylphenol(BHT)) $15 \mathrm{~mL}$ 를 가하여 2분 간 격렬히 혼합한 다음 암실에서 정치시켜 $n$-hexane층을 분리하였다. 지용성 성분이 추출된 $n$-hexane층은 sodium sulfate anhydrous가 채워진 유리관에 통과시켜 $50 \mathrm{~mL}$ 정용 플라스크에 수집하였다. 이 과정을 3회 반복한 후 수거된 추출용액을 $50 \mathrm{~mL}$ 로 정용하여 잘 혼합하여 분석을 위한 추출액으로 사용하였다.

\section{레티놀 및 베타카로틴 분석(HPLC)}

레티놀과 베타카로틴 분석은 saponification으로 추출한 추출액을 HPLC를 이용하여 동시분석법으로 분석하였다 (15). 시험관에 추출액 $10 \mathrm{~mL}$ 를 취하여 질소로 용매를 휘발 시킨 후 재용해 용매(ethanol:chloroform=4:1, v/v) $1 \mathrm{~mL}$ 에 재용해하였다. 다음으로 $0.45 \mu \mathrm{m}$ membrane filter(Advantec, Tokyo, Japan)로 여과하여 HPLC(Agilent, Santa Chlara, CA, USA)로 분석하였다. 분석에 사용된 칼럼은 Vydac 201TP $\mathrm{C}_{18}(4.6 \times 250 \mathrm{~mm}, 5 \mu \mathrm{m}$, GRACE, Santa Clara, CA, USA)이며 검출기는 photodiode array detector(PDA, Agilent)를 사용하 여 레티놀과 베타카로틴을 각각 $325 \mathrm{~nm}$ 와 $452 \mathrm{~nm}$ 에서 검출 하였다. 이동상은 methanol:butanol:water(6:1:3, v/v/v) 혼합 액을 이동상 A, methanol:butanol:water(89.5:10:0.5, v/v/v)를 이동상 $\mathrm{B}$ 로 사용하였으며 성분 분리를 위한 gradient 조건 으로는 초기 0-8분 동안 이동상 A $25 \%$ (이동상 B 75\%), 8-50분 동안 이동상 $\mathrm{A}$ 를 $90 \%$ 로 증가, 50-55분 동안 이동상 A $90 \%$ 유지, 이후 55-57분까지 이동상 $\mathrm{A}$ 를 $25 \%$ 로 감소시 킨 57-65분 동안 유지시켰다. 이동상 유량은 $1 \mathrm{~mL} / \mathrm{min}$ 이었 다. 레티놀 표준용액은 7 개의 농도(2.371, $1.186,0.593$, $0.296,0.148,0.074$ 및 $0.037 \mu \mathrm{g} / \mathrm{mL}$ ) 범위로, 베타카로틴은 6 개의 농도(2.483, $1.241,0.621,0.310,0.155$ 및 $0.078 \mu$ $\mathrm{g} / \mathrm{mL}$ )로 검량선을 작성하였으며 두 성분 모두 정량 분석 결과를 $\mu \mathrm{g} / 100 \mathrm{~g}$ 으로 나타내었다.

\section{비타민 E 함량 분석(HPLC)}

비타민 $\mathrm{E}$ 함량 분석은 식품공전법(14)에 따라 진행하였 다. 추출액 $2 \mathrm{~mL}$ 를 정확히 취하여 질소로 용매를 휘발시킨 다음 $\mathrm{n}$-hexane $1 \mathrm{~mL}$ 로 재용해하였다. 재용해된 추출액을 $0.5 \mu \mathrm{m}$ membrane filter(Advantec)로 여과하여 HPLC (LC-20AD, Shimadzu, Kyoto, Japan)로 분석하였다. 분석에 사용된 칼럼은 LiChrospher Diol $100(250 \times 4 \mathrm{~mm}, 5 \mu \mathrm{m}$ Merck, Darmstadt, Germany)을 사용하였으며, 형광검출기 (fluorescence detector, Shimadzu) 를 이용하여 $\operatorname{Ex} \lambda=285 \mathrm{~nm}$
와 $\mathrm{Em} \lambda=325 \mathrm{~nm}$ 에서 비타민 $\mathrm{E}$ 의 8 종 $\operatorname{homolog}(\mathrm{a}$ -tocopherol(T), $\beta-T, \gamma-T, \delta-T, a$-tocotrienol $\left(\mathrm{T}_{3}\right), \beta-\mathrm{T}_{3}, \gamma-\mathrm{T}_{3}$ 및 $\delta-T_{3}$ )를 모두 분리 검출하였다. 이동상은 $0.6 \%$ isopropanol을 함유한 $n$-hexane을 사용하였고, 이동상 유량 은 $1 \mathrm{~mL} / \mathrm{min}$, 분석시간은 50 분이었다. 검량선은 토코페롤 표준용액의 농도를 $\mathrm{a}-\mathrm{T}$ 는 $3.880,1.940,0.776,0.155 \mu \mathrm{g} / \mathrm{mL}$, $\beta-\mathrm{T}$ 는 $1.980,0.990,0.396,0.079 \mu \mathrm{g} / \mathrm{mL}, \gamma-\mathrm{T}$ 는 $9.720,4.860$, $1.944,0.389 \mu \mathrm{g} / \mathrm{mL}, \delta-\mathrm{T}$ 는 $3.100,1.550,0.620,0.124 \mu \mathrm{g} / \mathrm{mL}$ 로 제조하여 검량선을 작성하여 시료를 정량 분석하였다. 시료 중 $\mathrm{T}_{3}$ 가 존재하는 시료는 palm oil을 이용하여 $a-\mathrm{T}_{3}$ 와 $\beta-T_{3}$ 정성분석을 하였으며 $\alpha-T$ 와 $\beta-T$ 검량선을 이용하여 정량분석하였다(16). 각 tocopherol, tocotrienol 함량은 추출 용매와 시료의 양을 고려하여 $\mathrm{mg} / 100 \mathrm{~g}$ 으로 나타내었다. 비타민 $\mathrm{E}$ 함량은 활성을 나타내는 단위인 a-tocopherol equivalent(a-TE)를 다음 식을 이용하여 계산하였다.

$$
\begin{aligned}
\mathrm{a}-\mathrm{TE}(\mathrm{mg} / 100 \mathrm{~g})= & (\mathrm{a}-\mathrm{T} \times 1.0)+(\beta-\mathrm{T} \times 0.5)+(\gamma-\mathrm{T} \times 0.1)+(\delta \\
& -\mathrm{T} \times 0.01)+\left(\mathrm{a}-\mathrm{T}_{3} \times 0.3\right)+\left(\beta-\mathrm{T}_{3} \times 0.05\right)
\end{aligned}
$$

\section{콜레스테롤 함량 분석(유도체화 및 $\mathrm{GC}$ 분석)}

콜레스테롤 유도체화 및 GC 분석은 식품공전법(14)을 이용하였다. 먼저, 시험관에 추출액 $10 \mathrm{~mL}$ 을 정확히 취한 후 질소로 용매를 제거 시킨 후 acetone $3 \mathrm{~mL}$ 을 가하고 용매를 질소로 완전히 제거하여 유도체화를 진행하였다. 건조된 시험관에 dimethyl formamide(DMF) $3 \mathrm{~mL}$ 를 가하여 혼합한 후 이를 새로운 시험관에 $1 \mathrm{~mL}$ 취하여 $0.2 \mathrm{~mL}$ hexamethyldisilazane과 $0.1 \mathrm{~mL}$ 의 trimethylchlorosilane을 가 한 후 마개를 닫고 30 초간 진탕한 다음 약 15 분간 상온에서 정치하였다. 각 시험관에 $5 a$-cholestane $(0.1 \mathrm{mg} / \mathrm{mL}$ in heptane, IS) $1 \mathrm{~mL}$ 과 증류수 $10 \mathrm{~mL}$ 를 가한 후 마개를 닫고 30 초간 혼합하였다. 다음으로 15 분간 정치시키고 분리된 heptane 층을 취하여 sodium sulfate column을 통과시켰다. 탈수된 여액을 GC(HP 5890 Series ПI, Hewlett Packard Co., Palo Alto, CA, USA)로 분석하였다. 분석 칼럼은 Agilent J\&W HP-5(30 m×0.320 mm, $0.25 \mu \mathrm{m}$, Agilent, Santa Clara, $\mathrm{CA}, \mathrm{USA}$ )를 사용하였다. 검출기는 flame ionization detector(FID)를 사용하였고, 검출 온도는 $300^{\circ} \mathrm{C}$, carrier gas 는 질소를 $3 \mathrm{~mL} / \mathrm{min}$ 으로 사용하였다. 추출액의 주입부 온 도는 $300^{\circ} \mathrm{C}$ 이며, 칼럼 온도는 초기 $260^{\circ} \mathrm{C}$ 에서 $3^{\circ} \mathrm{C} / \mathrm{min}$ 으로 $300^{\circ} \mathrm{C}$ 까지 증가시킨 후 유지시켰다. 각각의 $0.198,0.099$, $0.0495,0.0099,0.00495,0.002472 \mathrm{mg} / \mathrm{mL}$ in dimethyl formamide 농도의 콜레스테롤 표준용액에 유도체화 과정 에서 첨가된 내부표준물질 5a-cholestane의 area로 나눈 값 (cholesterol area/5a-cholestane area)으로 검량선을 작성하 여 각 콜레스테롤 함량을 정량하였다. 검량선에 시료의 분 석결과로 얻어진 peak area를 대입하고 추출 용매량과 시료 무게를 고려하여 $\mathrm{mg} / 100 \mathrm{~g}$ 으로 나타냈다. 


\section{분석법 검증}

지용성 비타민 및 콜레스테롤 분석법의 유효성 검증은 단일실험실(single laboratory)을 위한 $\mathrm{AOAC}(17)$ 와 $\mathrm{FDA}(18)$ 의 분석법 검증 가이드라인에 준하여 검증하였으 며 방법은 다음과 같다. 직선성은 표준물질을 단계적으로 희석하여 각 농도에서 3 회 반복으로 $\mathrm{GC}$ 와 $\mathrm{HPLC}$ 로 분석하 였다. 표준용액의 peak area과 농도를 변수로 검량선을 작성 하고 검량선의 상관계수 $\left(\mathrm{R}^{2}\right)$ 값을 이용하여 직선성을 확인 하였다. 검출한계(limit of detection, LOD) 및 정량한계(limit of quantification, LOQ)는 signal-to-noise $(\mathrm{S} / \mathrm{N})$ 비율에 기초 하여 공 시험액(blank)을 HPLC로 분석하여 얻은 크로마토 그램 $\mathrm{S} / \mathrm{N}$ 값의 평균과 표준편차를 구하였다. 평균에 각각 3 배, 10 배의 표준편차 값을 더하여 $\mathrm{LOD}$ 와 $\mathrm{LOQ}$ 를 구하였 고, $\mathrm{LOD}$ 이하의 수치는 $\mathrm{ND}$ (not detected)로 표시하였다. 정 확성 검증은 SRM $1849 \mathrm{a}$ 와 SRM 2358 를 사용하였으며, 분석값과 NIST에서 제시한 참고값(reference value)을 비교 하여 회수율(\%)로 나타내었다. 정밀성 검증은 시판되고 있 는 영아용 분유(infant formula, premium with mom, pasteur, Seoul, Korea)를 분석품질 관리(quality control, QC) 시료로 사용하여 하루에 독립적으로 3 반복으로 5 회 분석하여 반복 성을 평가하였으며, 3 반복으로 하루 1 회씩 5 일 동안 분석하 여 결과의 재현성을 평가하였다.

\section{분석품질관리}

분석품질관리는 내부 및 외부 수준으로 이루어졌으며 내부분석품질관리는 $\mathrm{AOAC}$ 가이드라인(17)에 준하여 분 석품질관리도표(quality control chart, $\mathrm{QC}$ chart)를 작성하여 관리하였다. $\mathrm{QC}$ 시료를 이용하여 최소 10 회 이상 분석하였 으며 상대표준편차가 $5 \%$ 이내에 들어가는 10 개의 분석값 과 이들의 평균값을 기준으로 관리 상·하한선(upper and lower control line, UCL and LCL)과 조치 상·하한선(upper and lower action line, UAL and LAL)을 계산하여 기준을 설정하였고, 시료 분석이 이루어지는 $\mathrm{QC}$ 시료를 함께 분석
하여 얻어진 결과값으로 $\mathrm{QC}$ chart를 작성하여 분석품질관 리를 위한 지표로 사용하였다. 관리 및 조치선은 다음과 같이 계산하여 설정하였다.

$\mathrm{UCL}$ and $\mathrm{LCL}=$ mean of analyte content $\pm 2 \times$ standard deviation

$\mathrm{UAL}$ and $\mathrm{LAL}=$ mean of analyte content $\pm 3 \times$ standard deviation

외부분석품질평가는 영국 식품환경연구청에서 주관하 는 국제 분석숙련도시험(analysis proficiency test)인 Food Analysis Performance Assessment Scheme(FAPAS)를 이용 하여 평가하였다. 참여한 FAPAS 시험의 시료는 콜레스테 롤은 mixed fat spread, 레티놀과 토코페롤은 infant formula 였으며 분석은 시료 분석에 사용된 검증된 분석법을 이용하 여 분석하였고 z-score를 비교하여 분석숙련도를 평가하였 다.

\section{결과 및 고찰}

\section{분석법 검증}

본 연구에서 지용성 비타민 및 콜레스테롤 분석에 관한 분석법 검증은 $\mathrm{AOAC}$ 분석법 검증 가이드라인(17)에 준하 여 직선성, $\mathrm{LOD}, \mathrm{LOQ}$, 정확성 및 정밀성을 분석 및 평가하 였다. 콜레스테롤 및 비타민 $\mathrm{A}, \mathrm{E}$ 의 직선성, $\mathrm{LOD}, \mathrm{LOQ}$ 는 Table 1 과 같다. 직선성 확인을 위해 각 성분에 대한 표준품 은 5-7개의 농도 수준을 설정하여 각각 3회에 걸쳐 측정 결과를 평균으로 하여 표준용액 검량선을 작성하였다. 작 성된 표준용액의 검량선의 상관계수 $\left(\mathrm{R}^{2}\right)$ 가 모두 0.9997 이 상으로 나타나 성분 분석의 직선성이 우수한 것을 확인할 수 있었다. HPLC 또는 GC 등을 활용한 기기분석법의 LOD 와 $\mathrm{LOQ}$ 는 값이 낮을수록 분석하고자 하는 항목의 검출능

Table 1. Linearity, limit of detection, and limit of quantification of retinol, $\beta$-carotene, a-tocopherol, and cholesterol analyses

\begin{tabular}{|c|c|c|c|c|}
\hline Analytes & $\begin{array}{l}\text { Regression equation } \\
\qquad(y=a x+b)^{1)}\end{array}$ & $\begin{array}{c}\text { Correlation } \\
\text { coefficient }\left(\mathrm{R}^{2}\right)\end{array}$ & $\begin{array}{c}\mathrm{LOD}^{2)} \\
(\mu \mathrm{g} / 100 \mathrm{~g})\end{array}$ & $\begin{array}{c}\left.\mathrm{LOQ}^{3}\right) \\
(\mu \mathrm{g} / 100 \mathrm{~g})\end{array}$ \\
\hline Retinol & $y=204.15 x-0.9242$ & 0.9998 & 0.018 & 0.049 \\
\hline$\beta$-Carotene & $y=161.08 x-8.6993$ & 0.9997 & 0.064 & 0.087 \\
\hline a-Tocopherol & $y=(1 \times 106) x+22011$ & 0.9999 & 0.089 & 0.236 \\
\hline B-Tocopherol & $y=(1 \times 106) x+4980.7$ & 1.0000 & 0.098 & 0.258 \\
\hline y-Tocopherol & $y=(2 \times 106) x+38906$ & 0.9999 & 0.075 & 0.200 \\
\hline 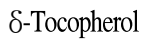 & $y=(2 \times 106) x-20255$ & 1.0000 & 0.072 & 0.161 \\
\hline Cholesterol & $y=10.286 x+0.0006$ & 0.9998 & 47.082 & 122.018 \\
\hline
\end{tabular}

\footnotetext{
1) $\mathrm{y}$ and $\mathrm{x}$ indicate peak area $(\mathrm{mAU})$ and concentration, respectively.

${ }^{2)}$ Limit of detection.

${ }^{3}$ Limit of quantification.
} 
이 우수하다고 할 수 있다(19). GC-FID를 이용한 콜레스테 롤 성분 분석에서 $\mathrm{LOD}$ 와 $\mathrm{LOQ}$ 는 각각 47.082 와 122.018 $\mathrm{\mu g} / 100 \mathrm{~g}$ 으로 나타났는데, 이는 Kim 등(20)이 GC-FID를 이용하여 콜레스테롤 분석 시 보고한 $\mathrm{LOD}(985 \mu \mathrm{g} / 100 \mathrm{~g})$ 와 $\mathrm{LOQ}(3284 \mu \mathrm{g} / 100 \mathrm{~g})$ 에 비하여 높은 검출 수준임을 확인할 수 있었다. HPLC-PDA를 이용한 레티놀과 베타카로틴 분 석의 $\mathrm{LOD}$ 와 LOQ는 각각 레티놀은 0.018 와 $0.049 \mathrm{\mu g} / 100$ $\mathrm{g}$ 이었으며, 베타카로틴은 0.064 와 $0.087 \mu \mathrm{g} / 100 \mathrm{~g}$ 으로 나타 났다. Kim 등(11)은 HPLC-FLD로 검출한 레티놀과 HPLC-UV로 검출한 베타카로틴 분석의 $\mathrm{LOD}$ 와 $\mathrm{LOQ}$ 는 각 각 레티놀 0.79 와 $3.15 \mathrm{\mu g} / 100 \mathrm{~g}$, 베타카로틴 0.81 와 2.03 $\mu \mathrm{g} / 100 \mathrm{~g}$ 이었다고 보고하였다. 본 연구에서 HPLC-PDA를 이용하여 레티놀과 베타카로틴을 동시검출법으로 검출하 였는데, 두 성분 모두 비교적 낮은 수준의 $\mathrm{LOD}$ 와 $\mathrm{LOQ}$ 를 나타내어 낮은 함량 수준으로 존재하는 식품의 정량분석에 도 적용 가능할 것으로 보여진다. 한편, 비타민 $\mathrm{E}$ 분석을 위해 HPLC-FLD를 이용하였는데, $\alpha-, \beta-, \gamma$ - 및 $\delta$-tocopherol 의 LOD는 각각 $0.089,0.098,0.075$ 및 $0.072 \mu \mathrm{g} / 100 \mathrm{~g}$ 으로 나타났으며, $\mathrm{LOQ}$ 는 각각 $0.236,0.258,0.200$ 및 $0.161 \mu$ $\mathrm{g} / 100 \mathrm{~g}$ 으로 나타났다. HPLC-PDA법으로 비타민 E를 분석 한 Lee 등(21)은 부착된 칼럼에 따라 LOD가 0.02-0.06, 0.06, $0.05-0.12, \quad 0.04-0.22$ 로 LOQ가 $0.07-0.21, \quad 0.18-0.20$, 0.15-0.40, 0.14-0.72 $\mathrm{\mu g} / 100 \mathrm{~g}$ 라 보고하였다. 본 연구에서의 $\mathrm{LOD}, \mathrm{LOQ}$ 가 비교적 높은 값을 나타내었으나, 분석한 시료 의 함량 표시를 $\mathrm{mg} / 100 \mathrm{~g}$ 을 사용하고 있으며 $\mathrm{a}-\mathrm{T}$ 의 LOQ에
비해 검출된 모든 시료 중 $0.01 \mathrm{mg} / 100 \mathrm{~g}$ 이 가장 낮은 값으 로 정량의 어려움이 없을 것으로 보인다. 분석의 정확성과 정밀성은 분석법에 의해서도 영향을 받지만 동일한 분석법 일지라도 분석하려는 성분의 농도에 따라 크게 영향을 받는 다. 이 때문에 $\mathrm{AOAC}$ 가이드라인에서는 성분의 농도에 따 라 정확성과 정밀성의 수용범위를 다르게 제시하고 있다 (17). 분석하고자 하는 시료의 농도 수준이 $1 \mathrm{mg} / 100 \mathrm{~g}$ 인 경우 수용되는 회수율의 범위는 80-115\%인 반면, $1 \mathrm{\mu g} / 100$ $\mathrm{g}$ 인 경우 70-125\%로 수용범위가 넓어진다. 본 연구에서 콜레스테롤, 레티놀, 베타카로틴, 토코페롤의 정확성은 Table 2와 같다. 모든 성분의 회수율이 $95.6-101.1 \%$ 로 $\mathrm{AOAC}$ 가이드라인에서 수용 가능한 범위에 충족하여 우수 한 정확성을 보였다. 또한 정밀성을 검증하기 위해 사용되 는 반복성과 재현성의 상대표준편차(relative standard deviation, RSD) 범위도 성분의 농도 수준이 약 $1 \mathrm{mg} / 100$ $\mathrm{g}$ 인 경우 $6 \%$ 및 $11 \%$ 이하 수준으로 수용되나 농도가 1 $\mathrm{\mu g} / 100 \mathrm{~g}$ 인 경우 $15 \%$ 및 $32 \%$ 로 수용되는 범위가 넓어진다. 정밀성은 Table 3 과 같다. 반복성(repeatability)의 RSD는 0.9-1.3\% 범위를 나타내었으며 재현성(reproducibility)은 1.1-5.9\%로 나타나 우수한 정밀성을 확인하였다.

\section{분석품질관리}

내부분석품질관리는 QC chart를 이용하여 관리(Fig. 1)하 였으며 외부적으로는 국제분석숙련도 시험(Table 4)을 통 해 평가하였다. Fig. 1 은 시료 분석 기간 동안 검증된 분석법

Table 2. Accuracy of retinol, $\beta$-carotene, $a$-tocopherol, and cholesterol analyses

\begin{tabular}{ccccc}
\hline Analytes & SRM $^{1)}$ & Reference value $^{2)}$ & Analytical value $^{3)}$ & Recovery $(\%)$ \\
\hline Retinol $(\mu \mathrm{g} / 100 \mathrm{~g})$ & SRM 1849a & $768 \pm 23$ & $776.29 \pm 3.34$ & 101.1 \\
B-Carotene $(\mu \mathrm{g} / 100 \mathrm{~g})$ & SRM 3251 & $3640 \pm 560$ & $3806.54 \pm 173.48$ & 95.6 \\
a-Tocopherol $(\mathrm{mg} / 100 \mathrm{~g})$ & SRM $1849 \mathrm{a}$ & $21.9 \pm 1.3$ & $21.56 \pm 0.08$ & 98.6 \\
Cholesterol $(\mathrm{mg} / 100 \mathrm{~g})$ & SRM $1849 \mathrm{a}$ & $13.74 \pm 0.29$ & $13.81 \pm 0.15$ & 100.5 \\
\hline
\end{tabular}

${ }^{1)}$ SRM: standard reference materials, SRM 1849a: infant/adult nutritional formula, SRM 3251: saw palmetto.

${ }^{2)}$ The true value for the contents of corresponding analytes in SRM provided by NIST.

${ }^{3)}$ The analytical value obtained in this study.

Table 3. Precision of retinol, $\beta$-carotene, a-tocopherol, and cholesterol analyses

\begin{tabular}{ccccccc}
\hline \multirow{2}{*}{ Analytes } & \multicolumn{3}{c}{ Repeatability ${ }^{1)}$} & \multicolumn{3}{c}{ Reproducibility $^{2}$} \\
\cline { 2 - 7 } & Mean & SD $^{3)}$ & RSD (\%) & Mean & SD & RSD (\%) \\
\hline Retinol $(\mu \mathrm{g} / 100 \mathrm{~g})$ & 507.92 & 6.72 & 1.3 & 507.95 & 5.79 & 1.1 \\
B-Carotene $(\mu \mathrm{g} / 100 \mathrm{~g})$ & 73.03 & 0.82 & 1.1 & 76.52 & 4.50 & 5.9 \\
a-Tocopherol $(\mathrm{mg} / 100 \mathrm{~g})$ & 9.12 & 0.08 & 0.9 & 9.04 & 0.30 & 3.3 \\
Cholesterol $(\mathrm{mg} / 100 \mathrm{~g})$ & 49.88 & 0.55 & 1.1 & 48.90 & 0.90 & 1.8 \\
\hline
\end{tabular}

\footnotetext{
${ }^{1)}$ Repeatability refers to the results of independent 5 determination in triplicates obtained by analyzing a QC sample five times on the same day.

${ }^{2}$ Reproducibility refers to the results of independent 5 determinations in triplicates obtained by analyzing a QC sample five times on different days (once a day).

${ }^{3)}$ Standard deviation.

${ }^{4)}$ Relative standard deviation.
} 
으로 분석 시 기타 변동 요인에 의한 문제가 없는지 실험실 내에서 분석의 품질을 관리할 수 있는 $\mathrm{QC}$ chart로 분석 시 발생할 수 있는 환경, 기기 등에 의한 다양한 변수에
영향을 받는 분석 결과를 관찰할 수 있다. Fig. 1에 나타난 모든 분석값은 시료 분석과 동시에 이루어졌는데, 분석값

이 UCL과 LCL 범위 밖으로 벗어나는 경우, 분석 시스템에

Table 4. Analytical proficiency test (Food Analysis Performance Assessment Scheme) for retinol, a-tocopherol, and cholesterol

\begin{tabular}{ccccc}
\hline Analytes & Sample & Assigned value & Analytical value & z-Score \\
\hline Vitamin A $^{1)}(\mathrm{\mu g} / 100 \mathrm{~g})$ & Mixed fat spread & 52.8 & 50.03 & -0.6 \\
Vitamin $\mathrm{E}^{2)}(\mathrm{mg} / 100 \mathrm{~g})$ & Infant formula & 11.0 & 12.02 & 0.9 \\
Cholesterol $(\mathrm{mg} / 100 \mathrm{~g})$ & Infant formula & 521.0 & 508.90 & -0.2 \\
\hline
\end{tabular}

${ }^{1)}$ As retinol, the sum of cis- and trans-isomers.

${ }^{2)}$ As a-tocopherol content.

(A)

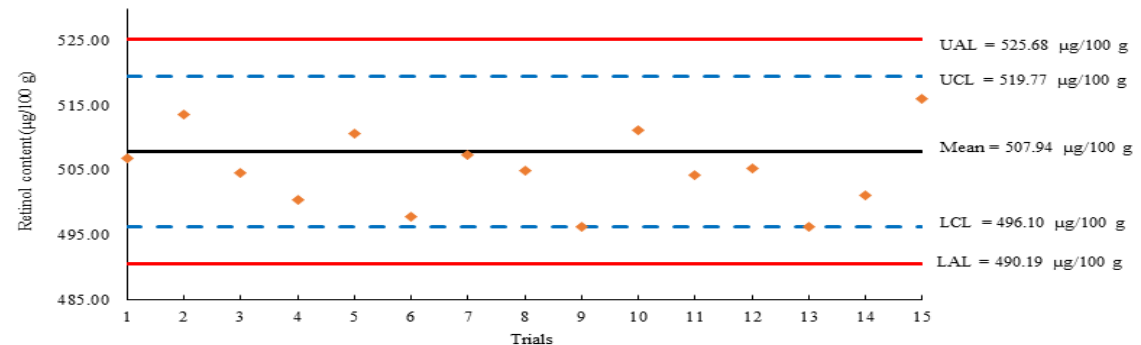

(B)

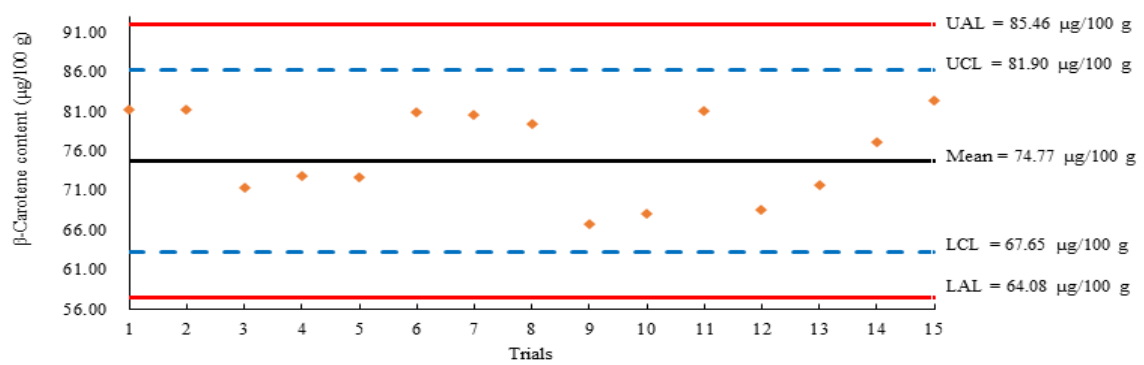

(C)
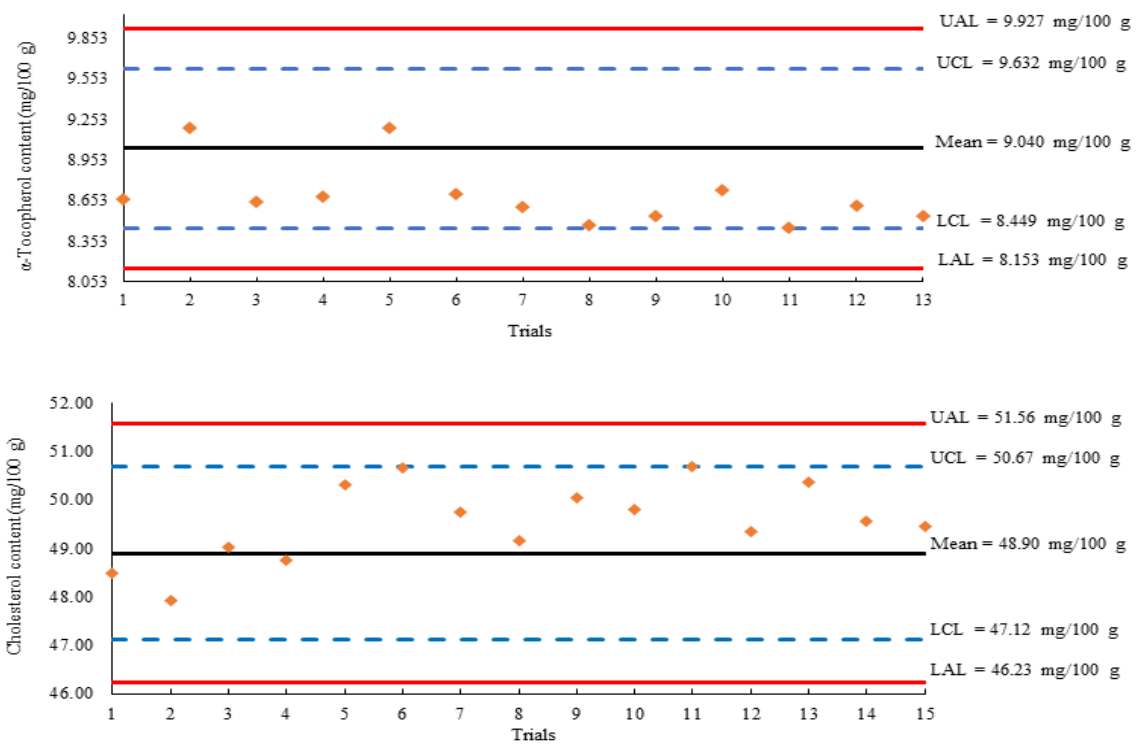

Fig. 1. Quality control charts of retinol, a-tocopherol, and cholesterol analyses. 
문제가 있다고 판단하여 분석 환경과 조건을 재점검하고 이 때 분석되었던 시료의 경우 재분석을 하여 결과값을 비교 검토하였다. 재분석한 결과값이 UCL 및 LCL 범위 안으로 나타나면 분석이 정상적으로 수행되었음으로 판단 하여 이때 분석된 시료의 분석값을 데이터로 채택하였다. Fig. 1에서 분석된 $\mathrm{QC}$ chart는 본 연구에서 분석된 25 종의 찜류 및 조림류의 콜레스테롤, 레티놀, 베타카로틴, 비타민 $\mathrm{E}$ 분석이 모두 수용가능한 분석시스템 하에서 진행되었음 을 보여주는 것으로 본 연구에서 얻어진 4종의 지용성 성분 에 대한 분석값은 국가 데이터베이스로 활용할 수 있는 수준의 신뢰도를 갖고 있음을 나타낸다고 할 수 있다. 한편, 국제분석숙련도 시험에서 얻어진 $\mathrm{z}$-score는 표준점수 (standard score)라고도 하며, 표준편차를 단위로 하여 측정 값이 평균에서 벗어난 정도를 평가하는 것으로 $\mathrm{z}$-score가 0 에 가까울수록 우수한 결과라 할 수 있는데 일반적으로 \pm 2 이내의 범위를 나타내면 국제적인 분석숙련도를 갖고 있음을 나타내며 이 범위를 벗어나는 경우는 분석숙련도가 국제적 수준으로는 인정받지 못함을 나타낸다. 본 연구를 위해 국제분석숙련도 PT-21113와 PT-14195 시험에 참여한 결과 z-score가 레티놀 분석 - 0.6 , 토코페롤 분석 0.9 , 콜레 스테롤 분석 -0.2 를 얻었는데 모두 $|\mathrm{z}|<2$ 의 결과를 보여 본 연구에서 수행된 분석법은 국제적 수준으로도 분석숙련 도가 우수하게 수행되었음을 보여준다 하겠다.

\section{찜류 및 조림류의 레티놀 및 베타카로틴 함량}

비타민 $\mathrm{A}$ 는 정상적 인체의 성장과 시력 유지, 상피조직 의 분화 조절 및 배아의 성장 등에 주요 역할을 하며 체내 생합성이 되지 않아 식이를 통한 섭취를 해야 하는 필수영 양소이다(25). 비타민 $\mathrm{A}$ 는 달걀이나 유제품 등과 같은 동물 성 식품에 존재하는 레티놀 형태와 녹황색 채소, 과일 등과 같은 식물성 식품에 존재하는 카로티노이드 형태로 섭취할 수 있다(26).

한국 식단 중 찜류 및 조림류 25종에 대한 레티놀 및 베타카로틴 분석 결과는 Table 5 과 같다. 찜류 14 종의 레티 놀 함량은 0.00-155.13 $\mathrm{\mu g} / 100 \mathrm{~g}$ 의 범위를 나타냈으며, 이 중에서 해물콩나물찜, 꽈리고추찜, 찐고구마, 호박찜, 코다 리찜에서는 레티놀이 검출되지 않았다. 달걀을 사용하여 조리한 식단에서 비교적 레티놀 함량이 비교적 높게 나타났

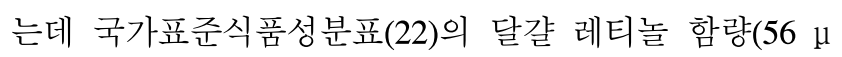
$\mathrm{g} / 100 \mathrm{~g})$ 에 비하여 본 연구의 달걀찜 $(24.54 \mathrm{\mu g} / 100 \mathrm{~g})$ 과 새우 젓 달걀찜 $(5.90 \mu \mathrm{g} / 100 \mathrm{~g})$ 은 낮은 함량을 나타냈다. 한편, 우유를 첨가한 달걀찜의 경우 레티놀 함량이 $155.13 \mathrm{\mu g} / 100$ $\mathrm{g}$ 으로 가장 높았는데 이는 우유의 레티놀 함량 때문으로 보여진다. 레티놀은 동물성 재료를 사용한 음식에서 주로 검출되었는데 육류 식단에서는 사태찜, 소갈비찜, 돼지갈 비찜 $(2.14-8.48 \mu \mathrm{g} / 100 \mathrm{~g})$ 등이 비교적 높았으며, 해산물 식 단에서는 가오리찜 $(50.85 \mu \mathrm{g} / 100 \mathrm{~g})$ 과 꼬막찜 $(9.69 \mu \mathrm{g} / 100$ g) 등이 비교적 높게 나타났다. 한편, 총 11종 조림류의 레티놀 함량은 0.00-85.11 $\mathrm{\mu g} / 100 \mathrm{~g}$ 의 범위를 보였는데, 식 물성 재료를 사용한 버섯조림, 콩조림, 마늘쫑조림, 연근조 림에서는 검출되지 않았으며 양미리 $(85.11 \mu \mathrm{g} / 100 \mathrm{~g})$, 달걀 $(49.21 \mathrm{\mu g} / 100 \mathrm{~g})$, 어묵 $(29.11 \mathrm{\mu g} / 100 \mathrm{~g})$ 등 동물성 재료를 사용한 조림류에서 비교적 높게 나타났다. Lee 등(23)은 닭고기의 조리방법에 따라 레티놀 함량의 차이가 나타났으 며, 찌기에 비하여 삶기가 닭고기의 레티놀 함량이 높게 나타났다고 보고하였다. 본 연구에서도 닭찜 $(4.73 \mathrm{\mu g} / 100$ $\mathrm{g})$ 에 비하여 닭조림 $(10.06 \mathrm{\mu g} / 100 \mathrm{~g})$ 이 나타나 유사한 결과 를 보였다.

찜류 및 조림류 25종의 베타카로틴 함량은 0.00-1203.23 $\mathrm{\mu g} / 100 \mathrm{~g}$ 의 범위로 종류에 따라 상당히 넓은 범위를 나타내 었다(Table 5). 달걀은 베타카로틴이 존재하지 않으므로 (22), 달걀만을 사용하여 조리한 달걀찜과 새우젓을 첨가한 달걀찜에서도 베타카로틴이 검출되지 않은 반면우유가 첨 가된 달갈찜의 경우 베타카로틴이 $183.63 \mu \mathrm{g} / 100 \mathrm{~g}$ 으로 높 은 함량을 보였다. 이는 우유 첨가 달걀찜의 경우 조리 시 부재료로 베타카로틴 함량이 높은 당근이 첨가된 때문인 것으로 보여진다. 동물성 식품인 돼지고기, 소고기, 닭고기 등은 베타카로틴을 함유하고 있지 않으나 본 연구에서 육류 를 재료로 사용된 찜과 조림류 식품에서도 베타카로틴이 검출된 것은 함께 조리된 식물성 부재료 때문인 것으로 보여진다. 일반적으로 한국 찜류 및 조림류는 고추, 고춧가 루 및 고추장과 같은 양념이 많이 사용되는데 보통 양념은 주재료가 아니기 때문에 영양성분에는 크게 영향을 미치지 못하지만 고추를 사용하는 양념의 경우는 고추 자체의 베타 카로틴 함량이 상당히 높기 때문에(28) 이러한 양념을 조리 에 사용 시 최종 식품의 베타카로틴 함량을 높이는데 영향 을미칠 수 있을 것으로 보인다. 한편, 총 11 종의 조림류 중에서는 달걀조림 $(1203.23 \mu \mathrm{g} / 100 \mathrm{~g})$ 이 가장 높은 베타카 로틴 함량을 나타내었는데 이는 첨가된 부재료 중 당근, 대파 등에 포함된 베타카로틴에 기인된 것으로 보여지며, 육류를 포함한 병어, 양미리 등 베타카로틴 함량이 없는 재료(22)를 사용한 식품에서도 첨가된 부재료에 의해 베타 카로틴 함량이 검출되는 것으로 보여진다.

한국은 레티놀 당량(retinol equivalent, RE)으로 비타민 $\mathrm{A}$ 를 나타내었으나, 2015년부터 레티놀 활성당량(retinol activity equivalent, RAE)을 비타민 A 기본단위로 사용하고 있다. 한국인 1 일 비타민 $\mathrm{A}$ 권장섭취량(RI)은 성인 남성 (19-29세) 기준 $800 \mu \mathrm{g} \mathrm{RAE}$ 이며 성인 여성(19-29) 기준 650 $\mu \mathrm{g} \mathrm{RAE}$ 로 권장되고 있다(24). 본 연구에서 분석한 25종의 찜류 및 조림류 식단의 권장섭취량은 베타카로틴 함량에 비하여 레티놀 함량이 많은 음식에서 높은 $\mu \mathrm{g} \mathrm{RAE}$ 를 나타 내는 것으로 보인다. 전체적으로 한국 찜류와 조림류는 대 체로 동물성과 식물성 재료를 고루 사용하여 조리되기 때문 에 베타카로틴과 레티놀 성분을 상당량 섭취할 수 있는 
Table 5. Vitamin A contents of steamed and braised dishes frequently consumed in Korea

\begin{tabular}{|c|c|c|c|c|}
\hline \multirow[b]{2}{*}{ Roman sample name } & \multirow[b]{2}{*}{ Descriptions } & \multicolumn{3}{|c|}{ Vitamin $A^{1)}$} \\
\hline & & $\begin{array}{c}\text { Retinol } \\
(\mu \mathrm{g} / 100 \mathrm{~g})\end{array}$ & $\beta$-Carotene $(\mu \mathrm{g} / 100 \mathrm{~g})$ & $\begin{array}{l}\text { ug RAE } / 100 \mathrm{~g} \\
(\% \text { of } \mathrm{RI})^{2)}\end{array}$ \\
\hline Dak-jjïm & Steamed chicken & $4.73 \pm 0.13$ & $\mathrm{ND}$ & $4.73(0.59)$ \\
\hline Dalgyal-jjim & Steamed egg & $24.58 \pm 0.86$ & $\mathrm{ND}$ & $24.58(3.07)$ \\
\hline Dalgyal-jjïm, saeujeot & Steamed egg with salted shrimp & $5.90 \pm 0.60$ & $\mathrm{ND}$ & $5.90(0.74)$ \\
\hline Dalgyal-jjïm, шооуи & Steamed egg with milk & $155.13 \pm 3.36$ & $183.63 \pm 6.36$ & $170.43(21.30)$ \\
\hline Dwaejigalbi-jjim & Steamed pork rib & $2.76 \pm 0.38$ & $503.05 \pm 40.39$ & $44.69(5.59)$ \\
\hline Gaori-jjim & Steamed ray & $50.85 \pm 0.41$ & $47.99 \pm 0.66$ & $54.85(6.86)$ \\
\hline Haemul-kongnamul-jjim & Steamed seafood with bean sprout & $\mathrm{ND}^{3)}$ & $348.05 \pm 11.93$ & $29.00(3.63)$ \\
\hline Hobak-jjim & Steamed zucchini & $\mathrm{ND}$ & $150.40 \pm 1.08$ & $12.53(1.57)$ \\
\hline Jjin-goguma & Steamed sweet potato & $\mathrm{ND}$ & $27.12 \pm 0.58$ & $2.26(0.28)$ \\
\hline Kkomak-jiim & Steamed cockle & $9.69 \pm 0.45$ & $21.55 \pm 0.86$ & $11.48(1.44)$ \\
\hline Kkwarigochu-jjïm & Steamed Shishito peppers & $\mathrm{ND}$ & $356.34 \pm 0.88$ & $29.70(3.71)$ \\
\hline Kodari-jjïm & Steamed pollack & $\mathrm{ND}$ & $102.30 \pm 3.50$ & $8.53(1.07)$ \\
\hline Satae-jiim & Steamed beef beef shank & $8.48 \pm 0.61$ & $21.94 \pm 0.84$ & $10.31(1.29)$ \\
\hline Sogalbi-jjim & Steamed beef rib & $2.14 \pm 0.10$ & $244.80 \pm 11.22$ & $22.54(2.82)$ \\
\hline Beaseot-jorim & Braised mashroom & $\mathrm{ND}$ & $\mathrm{ND}$ & $0.00(0.00)$ \\
\hline Byeongeo-jorim & Braised pomfret & $7.12 \pm 0.48$ & $47.54 \pm 2.64$ & $11.08(1.38)$ \\
\hline Dakjorim & Braised chicken & $10.06 \pm 0.08$ & $16.21 \pm 1.20$ & $11.42(1.43)$ \\
\hline Dalgyal-jorim & Braised egg & $49.21 \pm 0.17$ & $1203.23 \pm 16.62$ & $149.48(18.69)$ \\
\hline Dwaejigogi-mechurial-jang-jorim & Braised pork and quail egg & $26.16 \pm 0.18$ & $5.40 \pm 0.00$ & $26.61(3.33)$ \\
\hline Eomuk-jorim & Braised fish cake & $29.11 \pm 0.13$ & $76.51 \pm 2.27$ & $35.48(4.44)$ \\
\hline Kong-jorim & Braised black soybean & $\mathrm{ND}$ & $17.70 \pm 0.50$ & $1.48(0.18)$ \\
\hline Maneuljong-jorim & Braised garlic stem & $\mathrm{ND}$ & $107.27 \pm 65.83$ & $58.44(7.30)$ \\
\hline Sogogi-mechurial-jang-jorim & Braised beef and quail egg & $21.78 \pm 0.28$ & $7.39 \pm 0.04$ & $22.39(2.80)$ \\
\hline Yangmiri-jorim & Braised sand eel & $85.11 \pm 2.99$ & $36.73 \pm 1.52$ & $88.17(11.02)$ \\
\hline Yeongeun-jorim & Braised lotus root & $\mathrm{ND}$ & $\mathrm{ND}$ & $0.00(0.00)$ \\
\hline
\end{tabular}

${ }^{1)}$ Vitamin A activity is expressed as $\mu \mathrm{g}$ RAE (retinol activity equivalent)/100 g. $1 \mu \mathrm{g}$ RAE $=\mu \mathrm{g}$ retinol $+1 / 12 \mu \mathrm{g} \beta$-carotene.

${ }^{2)} \%$ of RI (recommended intake)=100×(vitamin content in sample/RI for Korean man). RIs for adult men and women at the age of $19-29$ are 800 and $650 \mu \mathrm{g}$ RAE for vitamin A, respectively.

${ }^{33}$ Not detected.

급원 식단이 되는 것으로 보여지며, 일반적으로 한 끼 식사 에서 이 외에도 다른 반찬류를 같이 섭취하는 한국인 식습 관으로 볼 때 일일 비타민 $\mathrm{A}$ 의 섭취를 균형적으로 유지할 수 있을 것으로 보여진다.

\section{찜류 및 조림류의 비타민 $\mathrm{E}$ 함량}

비타민 $\mathrm{E}$ 는 섭취 시 체내 생성되는 활성산소로 인해 발생 하는 각종 만성 질환 예방에 효과적인 항산화 작용을 하는 것으로 알려있으며, 식품 중 8종류의 homolog 형태(a-T, $\beta-T, \gamma-T, \delta-T, a-T_{3}, \beta-T_{3}, \gamma-T_{3}$ 및 $\delta-T_{3}$ 로 존재하며 체내에서 의 비타민 $\mathrm{E}$ 활성은 $\mathrm{a}-\mathrm{TE}$ 를 사용하여 계산할 수 있다. $\mathrm{a}-\mathrm{T}$ 를 제외한 나머지 종류의 비타민 $\mathrm{E}$ 는 섭취 시 체내 수송 단백질 과 친화력이 미미하기 때문에 식품 중 8 종의 비타민 $\mathrm{E}$ 함량
을 분석한 후 이에 대한 각각의 체내 활성도를 고려하여 a-TE로 산출하게 된다(29). 본 연구에서는 찜류 및 조림류 총 25 종에 대한 비타민 E 8종을 분석하고 a-TE 산출을 위해 $8-\mathrm{T}_{3}$ 및 $\delta-\mathrm{T}_{3}$ 을 제외한 6 종 비타민 $\mathrm{E}$ homolog 함량과 $\mathrm{a}-\mathrm{TE}$ 값을 Table 6에 나타내었다.

총 14 종 찜류의 $a-\mathrm{TE}$ 함량은 $0.33-1.85 \mathrm{mg} / 100 \mathrm{~g}$ 의 범위를 나타냈으며, 달걀찜 $(1.85 \mathrm{mg} / 100 \mathrm{~g})$, 꼬막찜 $(1.68 \mathrm{mg} / 100$ $\mathrm{g})$, 꽈리고추찜 $(1.60 \mathrm{mg} / 100 \mathrm{~g})$ 의 순으로 높게 나타났다. 반면, 사태찜 $(0.53 \mu \mathrm{g} / 100 \mathrm{~g})$, 소갈비찜 $(0.50 \mathrm{mg} / 100 \mathrm{~g})$, 닭찜 $(0.33 \mathrm{mg} / 100 \mathrm{~g})$, 돼지갈비찜 $(0.65 \mathrm{mg} / 100 \mathrm{~g})$ 과 같은 육류를 주재료로 사용한 음식은 비교적 낮은 $a-\mathrm{TE}$ 를 나타냈다. 이는 Lee 등(30)의 연구에서 육류의 a-TE가 0.1-0.4 mg/100 $\mathrm{g}$ 으로 보고한 값에 비하여 높은 $\mathrm{a}-\mathrm{TE}$ 값을 보였는데 이는 
부재료의 종류에 의한 차이로 보여진다. 한편, 식물성 재료 를 주로 사용한 찐고구마 $(1.08 \mathrm{mg} / 100 \mathrm{~g})$, 호박찜 $(0.81$ $\mathrm{mg} / 100 \mathrm{~g})$, 꽈리고추찜 $(1.60 \mathrm{mg} / 100 \mathrm{~g})$ 등은 육류 식단에 비하여 비교적 높은 a-TE를 나타내었는데, 이는 비타민 $\mathrm{E}$ 가 채소나 아몬드, 대두, 잣 등의 견과류, 종실류 또는 식물성 기름 등이 주요 급원식품(8)으로 식물성 재료 조리 시 첨가되는 콩기름, 참기름 등의 유지류에서 기인되는 비 타민 $\mathrm{E}$ 함량이 영향을 준 것으로 보인다.

총 11 종의 조림류의 $\mathrm{a}$-TE는 $0.09-1.76 \mathrm{mg} / 100 \mathrm{~g}$ 의 범위를 나타났으며 달걀조림 $(1.76 \mathrm{mg} / 100 \mathrm{~g})$, 콩조림 $(1.69 \mathrm{mg} / 100$ $\mathrm{g})$, 마늘쫑조림 $(1.50 \mathrm{mg} / 100 \mathrm{~g})$ 이 비교적 높은 함량을 나타 내었다. 대부분 a-T 함량이 가장 높은 수준으로 검출되는데 식물성 재료가 주로 사용된 콩조림 $(4.95 \mathrm{mg} / 100 \mathrm{~g})$, 마늘쫑
조림 $(2.63 \mathrm{mg} / 100 \mathrm{~g})$, 연근조림 $(1.97 \mathrm{mg} / 100 \mathrm{~g})$ 의 경우 $\mathrm{\gamma}-\mathrm{T}$ 함량이 가장 높은 것으로 나타났다. Ahn 등(8)은 2013-2015 년 국민건강영양조사에서 $\mathrm{\gamma}$-T의 섭취 기여율이 높은 식품 군이 유지류, 두류, 채소류라고 보고하였는데, 본 연구에서 도 동물성 재료를 사용하여 조리한 음식류에 비하여 식물성 재료가 사용된 음식류에서 $\mathrm{\gamma}-\mathrm{T}$ 함량이 더 높은 유사한 결과 를 확인할 수 있었다. 한편, 국가표준식품성분표(22)에서 버섯류는 비타민 $\mathrm{E}$ 함량이 존재하지 않는 것으로 보고되어 있으나 본 연구에서는 버섯조림이 $0.09 \mathrm{mg} / 100 \mathrm{~g}$ 으로 낮은 $\mathrm{a}-\mathrm{TE}$ 를 나타냈는데 이는 버섯 이외에 첨가된 부재료에 기 인한 것으로 보인다. '2015 한국인 영양소 섭취기준'에 따르 면 비타민 $\mathrm{E}$ 의 충분섭취량은 성별에 상관없이 19 세 이상 성인 기준 $12 \mathrm{mg}$ a-TE이며, 상한섭취량은 $540 \mathrm{mg}$ a-TE로

Table 6. Vitamin E profiles of steamed and braised dishes frequently consumed in Korea

\begin{tabular}{|c|c|c|c|c|c|c|c|}
\hline \multirow{2}{*}{ Roman sample name } & \multicolumn{7}{|c|}{ Tocopherol and tocotrienol contents $(\mathrm{mg} / 100 \mathrm{~g})$} \\
\hline & $a-T$ & $\beta-T$ & $\gamma-T$ & $\delta-\mathrm{T}$ & $\mathrm{a}-\mathrm{T} 3$ & $\beta-\mathrm{T} 3$ & $\mathrm{a}-\mathrm{TE}^{1)}(\% \text { of } \mathrm{AI})^{2)}$ \\
\hline Dak-j̈̈m & $0.30 \pm 0.00$ & $\mathrm{ND}^{3)}$ & $0.25 \pm 0.01$ & $0.27 \pm 0.00$ & ND & ND & $0.33(2.8)$ \\
\hline Dalgyal-jjïm & $1.82 \pm 0.05$ & $\mathrm{ND}$ & $0.23 \pm 0.00$ & $\mathrm{ND}$ & $0.04 \pm 0.00$ & ND & $1.85(15.4)$ \\
\hline Dalgyal-jjim, saeujeot & $0.47 \pm 0.10$ & $0.01 \pm 0.00$ & $0.13 \pm 0.02$ & $\mathrm{ND}$ & $0.02 \pm 0.01$ & ND & $0.50(4.2)$ \\
\hline Dalgyal-jjïm, шооуи & $1.51 \pm 0.14$ & $\mathrm{ND}$ & $0.34 \pm 0.02$ & $0.01 \pm 0.00$ & $0.05 \pm 0.00$ & ND & $1.56(13.0)$ \\
\hline Dwaejigalbi-jjim & $0.59 \pm 0.04$ & $0.03 \pm 0.00$ & $0.09 \pm 0.01$ & $0.83 \pm 0.03$ & $0.10 \pm 0.02$ & $0.00 \pm 0.00$ & $0.65(5.4)$ \\
\hline Gaori-jjim & $0.41 \pm 0.02$ & $0.01 \pm 0.00$ & $0.40 \pm 0.02$ & $0.01 \pm 0.00$ & $\mathrm{ND}$ & ND & $0.46(3.8)$ \\
\hline Haemul-kongnamul-jjim & $1.06 \pm 0.02$ & $0.25 \pm 0.01$ & $0.48 \pm 0.01$ & $0.08 \pm 0.00$ & $\mathrm{ND}$ & $\mathrm{ND}$ & $1.24(10.3)$ \\
\hline Hobak-jjim & $0.63 \pm 0.03$ & $\mathrm{ND}$ & $1.70 \pm 0.06$ & $0.42 \pm 0.02$ & $0.03 \pm 0.00$ & ND & $0.81(6.8)$ \\
\hline Jjïn-goguma & $0.85 \pm 0.02$ & $0.47 \pm 0.05$ & $\mathrm{ND}$ & $\mathrm{ND}$ & $\mathrm{ND}$ & $\mathrm{ND}$ & $1.08(9.0)$ \\
\hline Kkomak-jijm & $1.57 \pm 0.06$ & $0.16 \pm 0.01$ & $0.17 \pm 0.02$ & $0.46 \pm 0.01$ & $\mathrm{ND}$ & ND & $1.68(14.0)$ \\
\hline Kkwarigochu-jjim & $1.45 \pm 0.05$ & $0.08 \pm 0.00$ & $1.02 \pm 0.04$ & $0.02 \pm 0.00$ & $0.02 \pm 0.00$ & $0.15 \pm 0.00$ & $1.60(13.4)$ \\
\hline Kodari-jïim & $0.96 \pm 0.03$ & $0.03 \pm 0.00$ & $0.75 \pm 0.06$ & ND & $0.03 \pm 0.01$ & ND & $1.06(8.8)$ \\
\hline Satac-jïm & $0.49 \pm 0.02$ & $\mathrm{ND}$ & $0.33 \pm 0.02$ & $0.18 \pm 0.00$ & $0.02 \pm 0.00$ & ND & $0.53(4.4)$ \\
\hline Sogalbi-jjim & $0.47 \pm 0.02$ & $\mathrm{ND}$ & $0.23 \pm 0.02$ & $0.29 \pm 0.03$ & $\mathrm{ND}$ & ND & $0.50(4.2)$ \\
\hline Beaseot-jorim & $0.01 \pm 0.00$ & $\mathrm{ND}$ & $0.75 \pm 0.03$ & $0.12 \pm 0.01$ & $\mathrm{ND}$ & ND & $0.09(0.8)$ \\
\hline Byeongeo-jorim & $0.81 \pm 0.04$ & $\mathrm{ND}$ & $0.70 \pm 0.03$ & $0.08 \pm 0.00$ & $0.01 \pm 0.00$ & ND & $0.88(7.3)$ \\
\hline Dak-jorim & $0.40 \pm 0.01$ & $\mathrm{ND}$ & $0.30 \pm 0.01$ & $0.50 \pm 0.02$ & $\mathrm{ND}$ & ND & $0.43(3.6)$ \\
\hline Dalgyal-jorim & $1.69 \pm 0.01$ & $0.06 \pm 0.00$ & $0.30 \pm 0.01$ & $\mathrm{ND}$ & $0.06 \pm 0.00$ & ND & $1.76(14.7)$ \\
\hline Dwaejigogi-mechurial-jang-jorim & $0.51 \pm 0.02$ & $\mathrm{ND}$ & $0.51 \pm 0.01$ & $\mathrm{ND}$ & $\mathrm{ND}$ & ND & $0.56(4.7)$ \\
\hline Eomuk-jorim & $0.82 \pm 0.01$ & $0.12 \pm 0.01$ & $1.78 \pm 0.05$ & $0.35 \pm 0.02$ & $0.01 \pm 0.00$ & $0.12 \pm 0.01$ & $1.07(8.9)$ \\
\hline Kong-jorim & $0.68 \pm 0.01$ & $0.98 \pm 0.02$ & $4.95 \pm 0.11$ & $2.40 \pm 0.01$ & $\mathrm{ND}$ & ND & $1.69(14.1)$ \\
\hline Maneuljong-jorim & $1.19 \pm 0.03$ & $0.07 \pm 0.00$ & $2.63 \pm 0.10$ & $0.53 \pm 0.01$ & $\mathrm{ND}$ & $\mathrm{ND}$ & $1.50(12.5)$ \\
\hline Sogogi-mechurial-jang-jorim & $1.03 \pm 0.01$ & $\mathrm{ND}$ & $0.17 \pm 0.00$ & $\mathrm{ND}$ & $0.03 \pm 0.00$ & $\mathrm{ND}$ & $1.06(8.8)$ \\
\hline Yangmiri-jorim & $0.36 \pm 0.02$ & $0.22 \pm 0.04$ & $0.07 \pm 0.01$ & $0.37 \pm 0.03$ & $\mathrm{ND}$ & ND & $0.48(4.0)$ \\
\hline Yeongeun-jorim & $0.82 \pm 0.01$ & $0.77 \pm 0.03$ & $1.97 \pm 0.02$ & $0.49 \pm 0.01$ & $0.01 \pm 0.00$ & ND & $1.41(11.7)$ \\
\hline
\end{tabular}

${ }^{1)}$ Vitamin $\mathrm{E}$ activity is expressed as mg a-tocopherol equivalent $(\mathrm{a}-\mathrm{TE}) / 100 \mathrm{~g}$. $\mathrm{a}-\mathrm{TE}=(\mathrm{a}-\mathrm{T} \times 1.0)+(\beta-\mathrm{T} \times 0.5)+(\gamma-\mathrm{T} \times 0.1)+(\delta-\mathrm{T} \times 0.01)+\left(\mathrm{a}-\mathrm{T}_{3} \times 0.3\right)+\left(\beta-\mathrm{T}_{3} \times 0.05\right)$. Among 8 vitamin $\mathrm{E}$ homologs, $\gamma-\mathrm{T}_{3}$ and $\delta-\mathrm{T}_{3}$ were not shown because they are not considered for calculation of $\mathrm{a}-\mathrm{TE}$.

2) $\%$ of $\mathrm{AI}$ (adequate intake) $=100 \times$ (a-TE of sample/AI in a-TE for adult men). AIs of vitamin $\mathrm{E}$ for adults (men and women over 19 years old) are $12 \mathrm{mg}$ a-TE.

${ }^{3)}$ Not detected. 
적용되어 있다(24). 본 연구에서 분석한 총 25 종의 찜류 및 조림류의 경우 비타민 $\mathrm{E}$ 섭취량은 충분섭취량 $12 \mathrm{mg}$ 에 대하여 0.76-15.43\%으로 나타났는데(Table 6) 이는 단일 식품으로 $100 \mathrm{~g}$ 을 섭취했을 때를 기준으로 계산한 값이기 때문에 일반적으로 이러한 찜과 조림 이외에도 다양한 반찬 류를 함께 섭취하는 한국 식단과 총 섭취량을 고려해 볼 때 구성 식단에 따라 비타민 $\mathrm{E}$ 충분섭취량을 충족할 수 있을 것으로 보인다.

\section{찜류 및 조림류의 콜레스테롤 함량}

한국 식단 중 14종의 찜류 및 11 종의 조림류의 콜레스테 롤 성분 분석결과는 Table 7 과 같다. 찜류 14 종의 콜레스테 롤 함량은 $0.00-189.25 \mathrm{mg} / 100 \mathrm{~g}$ 의 범위를 보였는데, 달걀찜 $(189.25 \mathrm{mg} / 100 \mathrm{~g})$ 이 가장 높게 나타났으며, 다음으로 우유 첨가 달걀찜 $(169.57 \mathrm{mg} / 100 \mathrm{~g})$, 새우젓 첨가 달걀찜(126.73 $\mathrm{mg} / 100 \mathrm{~g}$ ) 순으로 높게 나타났다. 수산물이 주재료인 가오 리찜 $(91.27 \mathrm{mg} / 100 \mathrm{~g})$, 해물콩나물찜 $(64.84 \mathrm{mg} / 100 \mathrm{~g})$, 코다 리찜 $(60.96 \mathrm{mg} / 100 \mathrm{~g})$, 꼬막찜 $(38.30 \mathrm{mg} / 100 \mathrm{~g})$ 등에서도 콜레스테롤이 상다량 검출되었으나, 상한섭취량( $\mathrm{UL}$, tolerable upper intake)에 미치지 못하는 12.8-30.4\% 수준이 었다. 반면, 찐고구마, 꽈리고추찜 등 채소류가 주재료이며 동물성 재료를 사용하지 않은 메뉴에서는 검출되지 않았으 나, 호박찜의 경우 부재료로 다진 소고기를 사용하여 콜레 스테롤 함량 $(12.25 \mathrm{mg} / 100 \mathrm{~g})$ 이 검출된 것으로 보여진다.

조림류 11 종은 찜류에 비하여 콜레스테롤 함량의 범위가 보다 넓은 $0.00-246.68 \mathrm{mg} / 100 \mathrm{~g}$ 수준을 나타냈다(Table 7). 콩조림, 마늘쫑조림, 버섯조림, 연근조림 등과 같이 식물성 재료들로 조리된 메뉴에서는 콜레스테롤이 검출되지 않았 으나, 달갈조림 $(246.68 \mathrm{mg} / 100 \mathrm{~g})$, 소고기 메추리알 장조림 $(181.88 \mathrm{mg} / 100 \mathrm{~g})$, 돼지고기 메추리알 장조림(177.59 $\mathrm{mg} / 100 \mathrm{~g}$ )은 상대적으로 높은 콜레스테롤 함량을 보이는 메뉴로 나타났다. 국가표준식품성분표(22)에서 삶은달걀 $(305.56 \mathrm{mg} / 100 \mathrm{~g})$ 과 삶은 메추리알 $(480.42 \mathrm{mg} / 100 \mathrm{~g})$ 의 콜 레스테롤 함량이 돼지갈비 $(103.53 \mathrm{mg} / 100 \mathrm{~g})$ 와 소갈비 $(64.65-86.01 \mathrm{mg} / 100 \mathrm{~g})$ 에 비하여 상당히 높은 것으로 보고 되어 있는데, 본 연구에서도 돼지고기 메추리알 장조림과 쇠고기 메추리알 장조림이 닭조림 $(70.32 \mathrm{mg} / 100 \mathrm{~g})$, 돼지갈 비찜 $(50.07 \mathrm{mg} / 100 \mathrm{~g})$, 소갈비찜 $(33.38 \mathrm{mg} / 100 \mathrm{~g})$ 과 같이 육류를 주로 사용한 메뉴보다 난류를 함께 조리한 메뉴에서 콜레스테롤 함량이 더 높게 나타났다(Table 7).

콜레스테롤은 비타민 $\mathrm{D}$, 세포의 이온교환, 각종 호르몬 의 합성, 담즙산 대사 등에 중요한 물질로서 생선 또는 육류 와 같은 동물성 식품을 통해 일장랭 섭취하는 것이 필요하 다. 그러나 과량의 콜레스테롤 섭취는 동맥경화 및 고지혈 증과 같은 심혈관 질환의 원인이 되기도 하여 한국인 영양 섭취기준에서는 하루 상한섭취량을 $300 \mathrm{mg}$ 이하로 섭취할 것을 권고하고 있다(24). Table 7에서 나타난 각 식단의 콜
레스테롤 상한섭취량(\% of UI)은 난류를 사용한 일부 메뉴 의 경우 콜레스테롤 일일섭취상한량의 상당수준에 이르는 것으로 보여진다. 하지만 이는 한 메뉴만으로 $100 \mathrm{~g}$ 까지 섭취했을 때를 기준으로 계산된 것으로, 보통 계란 한 개 무게를 중란 35-40 g, 왕란 40-50 g 정도임을 고려해 본다면 일반적으로 다양한 반찬류로 구성된 한국의 한 끼 식단에서 계란 메뉴로만 섭취하는 총량은 $100 \mathrm{~g}$ 섭취량보다 훨씬 못미치는 양이 된다. 따라서, 이러한 일부 메뉴를 통해 섭취 되는 콜레스테롤은 일일섭취상한량 수준에는 훨씬 못미치 는 수준이며 고른 식단을 통해 충분히 조정이 될 수 있을 것으로 보인다.

Table 7. Cholesterol contents of steamed and braised dishes frequently consumed in Korea

\begin{tabular}{|c|c|}
\hline Roman sample name & Cholesterol (mg/100 g) $(\%$ of UL) \\
\hline Dak-jjim & $66.22 \pm 1.75(22.1)$ \\
\hline Dalgyal-jijm & $189.25 \pm 8.38(63.1)$ \\
\hline Dalgyal-jjim, saeujeot & $126.73 \pm 5.70(42.2)$ \\
\hline Dalgyal-j̈̈m, шооуи & $169.57 \pm 3.57(56.5)$ \\
\hline Dwaejigalbi-jjim & $50.07 \pm 2.23(16.7)$ \\
\hline Gaori-jïm & $91.27 \pm 1.75(30.4)$ \\
\hline Haemul-kongnamul-jjim & $64.84 \pm 0.73(21.6)$ \\
\hline Hobak-jjim & $12.54 \pm 0.36(4.2)$ \\
\hline Jjïn-goguma & $\mathrm{ND}^{2)}$ \\
\hline Kkomak-jjim & $38.30 \pm 1.14(12.8)$ \\
\hline Kkwarigochu-jïm & $\mathrm{ND}$ \\
\hline Kodari-jjim & $60.96 \pm 1.26(20.3)$ \\
\hline Satae-jj̈̈m & $94.95 \pm 2.72(31.7)$ \\
\hline Sogalbi-jjim & $33.38 \pm 1.05(11.1)$ \\
\hline Beoseot-jorim & ND \\
\hline Byeongeo-jorim & $40.81 \pm 0.41(13.6)$ \\
\hline Dak-jorim & $70.32 \pm 1.11(23.4)$ \\
\hline Dalgyal-jorim & $246.68 \pm 2.84(82.2)$ \\
\hline Dwaejigogi-mechurial-jang-jorim & $177.59 \pm 2.64(59.2)$ \\
\hline Eomuk-jorim & $7.84 \pm 0.29(2.6)$ \\
\hline Kong-jorim & ND \\
\hline Maneuljong-jorim & $\mathrm{ND}$ \\
\hline Sogogi-mechurial-jang-jorim & $181.88 \pm 1.47(60.6)$ \\
\hline Yangmiri-jorim & $49.59 \pm 1.24(16.5)$ \\
\hline Yeongeun-jorim & ND \\
\hline
\end{tabular}

1) $\%$ of UL (tolerable upper intake level) $=100 \times$ (vitamin content in sample/UL for Korean man). ULs of cholesterol for adult men and women at the age over 19 are less than $300 \mathrm{mg}$ for cholesterol.

${ }^{2)}$ Not detected. 


\section{요 약}

본 연구는 한국인의 영양소별 누적섭취 기여도를 고려한 key food 식품 중 외식 및 가정식 찜류 및 조림류 25종을 선정하고 이를 표준조리법으로 조리한 후 이들에 대한 비타 민 $\mathrm{A}$, 비타민 $\mathrm{E}$ 및 콜레스테롤 함량을 분석하였다. 또한, 이를 국가식품영양성분 $\mathrm{DB}$ 로 활용하기 위한 분석데이터 의 신뢰성 확보를 위하여 분석법 검증 및 분석품질관리를 수행하였다. 찜류 및 조림류의 총 25종의 콜레스테롤 함량 은 $0.00-246.68 \mathrm{mg} / 100 \mathrm{~g}$ 의 범위를 나타냈다. 계란을 사용한 메뉴에서 콜레스테롤 함량이 가장 높았으며 다음으로 수산 물과 육류를 주재료인 사용한 메뉴에서 콜레스테롤 함량이 높게 나타났으나 메뉴별로 한 끼 식단에서 섭취되는 섭취량 을 고려해 볼 때 일일상한섭취량에는 못미치는 수준인 것으 로 나타났다. 한편, 이들 식품류의 레티놀 함량은 0.00-155.13 $\mu \mathrm{g} / 100 \mathrm{~g}$ 의 범위를 나타냈으며 식물성 재료를 사용한 콩조림, 마늘쫑조림, 버섯조림, 연근조림에서는 검 출되지 않았다. 베타카로틴 함량의 경우 0.00-1203.23 $\mu$ $\mathrm{g} / 100 \mathrm{~g}$ 의 범위를 나타내었는데, 식물성 재료를 사용한 메 뉴에서 높게 나타났으며 육류, 난류 및 어류 등 동물성이 주재료인 음식에서도 조리 시 첨가되는 고춧가루와 같은 양념에 의한 베타카로틴 함량이 검출되었다. 비타민 $\mathrm{E}$ 함량 은 0.09-1.85 mg a-TE/100 g의 범위를 나타냈으며 동물성 재료보다는 콩, 마늘쫑, 연근 등과 같은 식물성 재료를 사용 한 식단에서 높은 함량을 나타내었다. 본 연구에서 분석한 찜류와 조림류 식단의 경우 동물성 재료와 식물성 재료가 고루 사용되는 메뉴들로서 지용성 비타민인 A와 E가 낮은 수준이지만 비교적 고루 분포되어 하루 세 끼를 이들을 포함하여 다양한 식단으로 구성할 때 지용성 비타민의 좋은 급원이 될 수 있을 것으로 보인다. 본 연구에서 사용된 비타 민 $\mathrm{A}, \mathrm{E}$ 및 콜레스테롤 분석에 대한 검증 및 분석품질관리를 수행한 결과, 모든 지표에서 분석법 검증 가이드라인의 기 준에 충족하여 연구기간 동안 수행된 분석이 신뢰성 있게 진행되었으며 생산된 데이터의 신뢰도가 확보되어 본 연구 에서 생산된 데이터는 국가식품영양성분 데이터베이스로 활용될 수 있을 것으로 보인다.

\section{감사의 글}

본 연구는 2019년도 식품의약품안전처의 연구개발비 (17162MFDS082)로 수행되었으며 이에 감사드립니다.

\section{References}

1. Lim SH, Kim JB, Cho YS, Choi YM, Park HJ, Kim
SN (2013) National standard food composition tables provide the infrastructure for food and nutrition research according to policy and industry. Korea J Food Nutr, 26, 886-894

2. Jung IK, Han GJ, Choe JS, Lee JW (2003) A study on the development of 'food nutrient data base by portion commonly used'. Rural Life Sci, 24, 175-193

3. United States Development of Agriculture, Agricultural Research Service (2013) USDA national nutrient database for standard reference. United States Development of Agriculture, Washington DC, USA, $p$ 25

4. Ministry of Education, Culture, Sports, Science, and Technology (2005) The council for science and technology, subdivision on resources (JP). Standard tables of food composition in Japan - fifth revised and enlarged edition. Ministry of Education, Culture, Sports, Science, and Technology, Tokyo, Japan.

5. Yoon MO, Kim K, Hwang JY, Lee HS, Son TY, Moon HK, Shim JE (2014) Development of a fatty acids database using the Korea national health and nutrition examination survey data. J Nutr Health, 47, 435-442

6. Hong IS (2007) Efficient synthesis and self assembling property of retinyl ether. MS Thesis, Myong-Ji University, Korea, p 1-2

7. Kim SA, Jun SY, Joeng HJ (2016) Estimated dietary intake of vitamin A in Korean adults: based on the Korea national health and nutrition examination survey 2007-2012. J Nutr Health, 49, 258-268

8. Ahn SE, Jun SY, Kim SA, Ha KH, Jung HJ (2017) Current statue and trends in estimated intakes and major food groups of vitamin E among Korean adult: using the 1-6th Korean national health and nutrition examination survey. J Nutr Health, 50, 483-493

9. Park MS, Kweon SH, Oh KW (2017) Dietary cholesterol intake in the Korean national health and nutrition examination survey (KNHANES) VI (2013-2015). Korean J Community Nutr, 22, 520-528

10. Park SH, Song W, Chun J (2018) Analyses of cholesterol, retinol, $\beta$-carotene, and vitamin $\mathrm{E}$ contents in regional food of South Korea. J Korean Soc Food Sci Nutr, 47, 429-439

11. Kim JY, Park SR, Shin JA, Chun J, Lee J, Yeon JY, Lee WY, Lee KT (2013) B-carotene and retinol contents in Bap, Guk (Tang) and Jjigae of eat-out Korean foods. J Korean Soc Food Sci Nutr, 42, 1958-1965

12. Park YJ, Sung JH, Choi YM, Kim YH, Kim MH, Jeong 
HS, Lee J (2016) Analysis of vitamin E in agricultural processed foods in Korea. J Korean Soc Food Sci Nutr, 45, 771-777

13. Lee KJ, Cho MS (2009) Evaluation of the meat and poultry 'Jorim' model in Korean modern cookbooks. Korean J Food culture, 24, 478-485

14. Korea Food and Drug Administration (2011) Korean Food Standard Codex. Korea Food Drug Administration, Chungju, Korea, p 10-1-60, 61, 86, 87

15. Thomas JB, Kline MC, Gil LM, Yen JH, Duewer DL, Sniegoski LT, Sharpless KE (2001) Preparation and value assignment of standard reference material $968 \mathrm{c}$ fat-soluble vitamins, carotenoids, and cholesterol in human serum. Clin Chim Acta, 305, 141-155

16. Chun J, Lee J, Ye L, Exler J, Eitenmiller RR (2006) Tocopherol and tocotrienol contents of raw and processed fruits and vegetables in the United State diet. J Food compos Anal, 19, 196-204

17. AOAC (2002) AOAC guidelines for single laboratory validation of chemical methods for dietary supplements and botanicals. Association of Official Analytical Chemists, Gaithersburg, MD, USA, p 12-13

18. FDA (1994) ICH Q2 (R1) Validation of analytical procedures: text and methodology. 4 version. U.S. Food and Drug Administration, Silver Spring, MD, USA, p 11-12

19. Macdougall D, Crummett WB (1980) Guidelines for data acquisition and data quality evaluation in environmental chemistry. Anal Chem, 52, 2242-2249

20. Kim JM, Park JM, Yoon T, Leem D, Yoon C, Jeong J, Jeong IS, Kwak BM, Ahn JH (2011) Development of analysis method for cholesterol in infant formula by direct saponification. Korean J Food Sci Ani Resour, 31, 944-951

21. Lee HM, Kwak BM, Ahn JH, Jeong SH, Shim SL, Kim KS, Yoon T, Leem D, Jeong J (2011) Simultaneous determination of vitamin $\mathrm{A}$ and $\mathrm{E}$ in infant formula by HPLC with photodiode array detection. Korean J Food Sci Ani Resour, 31, 191-199
22. Rural Development Administration (RDA) (2017) National Standard Nurient Database. $9^{\text {th }}$ ed, Jeonju, Korea, p 99, 101, 357, 419

23. Lee JH, Lee HN, Shin JA, Chun J, Lee J, Lee KT (2015) Contents of fat-soluble nutrients (cholesterol, retinol, and a-tocopherol) in different parts of poultry meats according to cooking method. J Korean Soc Food Sci Nutr, 44, 234-241

24. The Korean Nutrition Society (2015) Dietary reference intakes for Koreans. The Korea Nutrition Society, Seoul, Korea, p 2, 11, 21-22, 25-26

25. Underwood BA, Arthur P (1996) The contribution of vitamin A to public health. FASEB J, 10, 1040-1048

26. Tang G (2010) Bioconversion of dietary provitamin A carotenoids to vitamin $\mathrm{A}$ in humans. Am J Clin Nutr, 91, 1468S-1473S

27. Ji HG (2005) Study for retinol/mesoporous silica nano hybrid materials. $\mathrm{Ph}$ D Thesis, SungKyunKwan University, Korea, p 1-2

28. Shin JA, Chun J, Lee J, Shin KY, Lee SK, Lee KT (2013) Determination of $\beta$-carotene and retinol in Korean noodles and bread products. J Korean Soc Food Sci Nutr, 42, 1949-1957

29. Institute of Medicine, National, Research Council (2000) Dietary reference intakes for vitamin $\mathrm{C}$, vitamin $\mathrm{E}$, selenium, and carotenoids. National Academy Press, Washington DC, USA, p 196-199

30. Lee SM, Lee HB, Lee J (2005) Analysis of vitamin E in some commonly consumed foods in Korea. J Korean Soc Food Sci Nutr, 34, 1064-1070 